\title{
Analysis of the Concept of "Natural Person" in Public Law and Private Law Relations
}

\author{
Lyazzat Begimjanovna Nyssanbekova
}

Gulmira Amangeldievna Mashimbaeva

Zhuldyz Talgatovna Sairambaeva

Kamilya Zhakipbekovna Altayeva

Kazakh National University named by Al-Farabi, Kazakhstan, 050000, Almaty,Karasay batyr Street, 95a

Moldir Abaevna Rahmetova

Zhetysu State University named by I.Zhansugurov, 050060, I.Zhansugurov Street, 187a, TaldyKorgan, Kazakhstan.

Doi:10.5901/mjss.2015.v6n5p83

\section{Abstract}

The authors consider the notion of "natural person" in public law and private law relations, because this term has no clear answer is not in the regulations, not in the legal literature. For profound judgment of the specified features the author addresses to the analysis of provisions of the general theory of the right that through their prism to consider the concept "legal entity". In essence, designation used in law "legal entity" is identical to the concept "person", "individual". The author offers some reflections of scientists - jurists on this matter. So, some authors support withdrawal from a scientific turn of the concept "legal entity", having replaced on such as "citizen", "aliens", "person of law", etc. The authors intended to summarize existing theoretical interpretations and of his vision on this issue.

Keywords: personality, legal capacity, a person, an individual, legal entity

\section{Introduction}

Development trends of the international law are not only expressed in regulation of the various relations between states, but also include increasing the role of the person who became one of the participants of the international relations and subjects of the international law. Shift of accents in the legal regulation from the social relations to the identity's interests, transfer of our society to the life in the market conditions, encourages increased role of the legal fields in the legal system of RK, that is, in turn, leads to the increased interest of the scientific society to the theoretical problems related with public law sphere, and one of them is undoubtedly problem of the individual international legal personality. As rightly been said by V.P. Tugarinov: «Nothing in society could be made without activities of its people. Objective character of the social laws does not exclude people's activities, since these activities transfer opportunities into the reality » (Tugarinov, 1955). At the same time, attention is drawn to the fact that recognition of the integration process's objectivity does not exclude possibility of influence from the side of subjects. Integration is mediated by the activities of its subjects who could accelerate or slow down its development. However, we will not dive into the consideration of the integration process issue, we will rather touch theoretical questions of the conceptual framework in capacity of the individual physical person.

\section{Methods}

Regulation of publicly legal and private-law relations of powerless subjects was and will always have the most important and a matter of principle the international right, including for determination of legal status of legal entity. Considering a question of such component of the status of the person as its definition should be noted "legal entity" that "application of this term has no universal recognition" (Abdrakhmanova \& Nyssanbekova, 2013). The term "legal entity" in legal literature and regulations is used differently. In this regard for definition of a legal status of the legal entity in the right it is necessary to find out the concept "legal entity". (Gorski, 2013) Starting consideration of a question of the legal entity it is necessary to address to a source of emergence of the concept "person" which for the first time appeared in Roman Law. The 
Roman lawyers did not subdivide persons of law on natural and legal entities. In texts of primary sources they (natural and legal entities) are not mentioned at all. There are some reasons to it. The first, the civil turn in Rome was based mainly on certain capable people, they possessed a leading role in it. Secondly, the concept of the personality of the Roman tradition is isolated from concept of the certain person as Romans knew to will capable, but not capable people, for example slaves. The third, this concept developed only later in the European right of times of reception. In Rome there was one concept - persona (Suleymenov, 2002).

The technical term "person" i.e. persona (in translation from Latin - "mask") - the term abstract also is used in those cases where it is necessary to designate the isolated right ability. "Face", "personality" "to represent" are the words designating the relation to the person, the person. To represent, i.e. to give to a thing or abstract concept the personality.

The modern right, based on the principle of equal rights of citizens, does not know such distinction, but, nevertheless, distinctions in connection with nationality, age, sex, marital status are carried out. Meanwhile, it is necessary to distinguish the person as biological identity from his representation in the right, i.e. person's physical. Certainly, these concepts are connected, but are not identical. It is indicative that this thesis does not maintain criticism even concerning the person whom often identify with the person of law.

\section{Results}

The person in itself not the person of law, it is done to that by the institutes of civil society organized by legal image. Technically it occurs by means of fiction of the legal entity. It is well-known that there was time when the person did not admit the person of law, and a number of conditions to which the majority of people did not correspond, for example, slaves (speaking tools, things), serfs was necessary for his recognition. Even the question of is discussed today, whether it is possible to consider as the person of law the person incapacitated, i.e. not possessing right subjectivity and carrying out the rights through representatives. Thus, the legal entity is not the person, that becomes owing to possession right subjectivity. It is fiction, intermediaries between the real world and a world of law. Though G. F. Shershenevich writes: "The legal entity is the person of law coinciding with the person ..."(Shershenevich, 1912). Zhyullio de la Morander agrees with it, it defines: "legal entities are human beings as they, everyone separately, are persons of law". (De La Morandiere, 1965). Also Parlett specifies that studying about "legal entities" first of all is directed on studying of legal status of "natural human faces", unlike other non-state educations, in particular legal entities" (Parlett, 2010).

At the same time Savinyi considered that the real person of law is only the person as "the volitional capacity personality" and that the subjective right is a sphere of manifestation of strong-willed power of "freedom" of the individual. Gelder brought the thesis to the logical end that "only the capable person" can be the person of law (Cheshire,1961). It is well-known that the problem of the person of law belongs to the central legal science as there is no consensus, approach to concepts of "person of law", "face", "the subject of legal relationship". In Roman Law and in the civil doctrine of feudalism of the concept "person of law" and "person" did not coincide as the person did not possess a legal personality and "jus gentium" was not the person of law jus civile, it was considered as a thing (Suleimenov, 2002). In the bourgeois right persons of law were understood as people who are called as "legal entities", and associations of people or the organization which are called as "legal entities".

\section{Discussion}

However, for profound judgment of the specified features it is expedient to address to the analysis of provisions of the general theory of the right that through their prism to consider the legal phenomenon designated in the name playing an important role in formation of a standard basis of any branch of the right. There is nothing "seditious" that the concept "person of law" expresses legal abstraction. On the contrary, by means of the category "person of law", in a general view reflecting various categories of persons which are provided by precepts of law, the maintenance of this or that branch of the right is unique to open. For example, the civil law provided such subjects, as the seller and the buyer, the lessor and the tenant, etc. The law of criminal procedure establishes presence of the following subjects: accused, the suspect who was injured, etc. As for administrative law, owing to a wide range of the public relations regulated by it, the list of his subjects is huge. Therefore, it is a question of legal abstractions, in a general view defining on whom action of these or those norms extends. Certainly, extent of generalization in relation to this or that type of the person of law can be various, we will tell: serviceman, serviceman of this or that type of military forces, serviceman of a certain military rank, etc. (Yakimov, 2003).

In modern legal theory under the subjects of law are recognized persons or organizations behind which special 
legal property (quality) of legal personality giving the chance to participate in various legal relationships with other organizations is recognized by law.

Some authors connect a category of the subject of law with the possibility of participation in legal relationships, rooted in the rule of law. In particular, E. Abashin believes that the subject of law - is a natural or legal person who, by virtue of the rule of law, can act as a member of legal relationships- carrier of subjective rights and legal obligations (Abashin, 2010). According to him, Subjects of law acquire this quality solely by virtue of legal norm. No legal norm - no the subject of law, as the relevant legal relationship is not provided. Obviously, full equalizing of the subject of law and the participant of legal relationship and definition of the first through recognition by the second, with reflection of this fact of the precept of law, in our opinion, doesn't correspond to an essence of the considered legal terms.

It should be noted that a question of the concept of the subject of law and the subject of legal relationships is very debatable. It is not only and not so much about the precise terminology in the law, it is a question of ratio of different, in fact, concepts. The concept of the subject of law is broader than the concepts of the subject of legal relationships. For example, born child is a person with legal capacity, i.e. a subject of law in a legal sense of word, but isn't a subject of legal relationships, as he doesn't participate in particular legal relationships.

The concept of the subject of law covers a person involved and a person is able to participate in the relationship. Conclusions about the identity of the concept of "Subjects of law" and "Subjects of legal relations" are made by S.F. Kechekyan who considered participants of legal relationship as subjects of law (Kechekyan, 1958).

The ability of participation in legal relationship is the ability of person to be the carrier of rights and of their implementation. This ability depends on a civil status of the person, whether from if he is a citizen of this country or the foreigner, has reached or not reached the age of majority, what his marital status ...

R. O. Halfina wrote: "Participants of legal relationship are the person or in a certain way organized public formation. Depending on nature of legal relationship in which participate the person, various parties of his personality reveal. He acts as a member of society, as a family member, as an employee applying his work on production as the official who is carrying out functions assigned to him and so on. All these properties reveal in different types of public relations" (Halfina, 1974).

According to R. O. Halfina the concept of the participant of legal relationship is narrower, than the concept of the subject of law. To us, it is thought, that in certain cases it is a variable phenomena, have different legal value. Such statement also corresponds to it: "The subject of legal relationship is a subject of law who uses the right capacity". Thus, the subjects of law are persons possessing right subjectivity.

Chechot D. M. notes that the development and improvement of concepts in jurisprudence means the enrichment of known concepts, their clarification and specification, replacing old with new concepts, because the former can not contain and capture the essential properties of changed real relationships of legal reality (Chechot, 1968).

In our opinion, it is expedient to understand the abstract person as the person of law (physical or legal) who is allocated with a certain volume of the abstract legal rights and duties. It will allow to bring necessary clarity in judgment of considered legal concept. Cesare Sanfillino claims that "the subject who, on the one hand, is the addressee of the objective right, and with another - the carrier right subject, has the legal name "persons". The person it possesses the personality who admits behind it a law and order and owing to this fact can be called in wide value "the legal personality". Therefore, the concept "person of law" and "person" coincide (Sanfillino, 2000). It is well-known that classical definition of persons of law is connected with such concepts as natural and legal entities. The concept "legal entity" (the Greek physis plus Latin persona) is specially legal for designation of the individual person of law unlike the person of law - the public education called by the legal entity. In essence, designation used in law "legal entity" is identical to the concept "person", "individual". The individual is the separately taken person the representative of mankind possessing peculiar psychophysical features. Legal entities participate in the relations as people, persons, as the person. Legal entities and their public educations can be allocated with the different legal status allowing them to be participants of these or those legal relationship, thus legal status can provide or not provide category of nationality of the person. So, for example, the legal entity, being the citizen of the Republic of Kazakhstan, can participate in the most widespread labor legal relationship - legal relationship of the worker and the employer in the business sphere. However not all authors unanimously speak in favor of a tendency of the use of definition "legal entity".

So, some authors support withdrawal from a scientific turn of the concept "legal entity" as the term reflects natural properties of the subject in a bigger measure as a psychophysical individual, instead of its public qualities. Application of such term as "citizens" who are used in the legislation and in literature are inappropriate as literal interpretation does not allow to apply it to foreign citizens, stateless persons. In this sense covering broader concept is the term "legal entities". The scientist S. S. Alekseev supported in due time introduction of such term (Alekseev, 1999). D. N. Bakhrakh, 
deepening knowledge of the specified system of subjects, fairly specified that more detailed differentiation of subjects is required (Bachrach, 1986). He suggested, in particular, citizens to divide into citizens of the USSR, foreigners and apatrides. It was thus noted that between branches of the right it is possible to see distinction and in the one whom they recognize as the subjects. So, for example, in private international law for the purpose of definition of a legal status of legal entities, their rights and duties in the territory of a certain state the national legal system of this state is applied. In particular, Art. 12 of Civil Code of the Republic of Kazakhstan means citizens of the Republic of Kazakhstan by legal entities, foreigners and stateless persons. It should be noted that the term "foreigner" is used by the legislation for designation of category of legal entities, instead of for designation defined the organizations. Owing to what foreign legal entities do not enter category of foreigners. However, some authors, in particular, Koretsky consider that "in legal abstraction legal persons - the same persons, as well as legal entities, foreign legal entities - the same foreigners, as well as foreign legal entities"(Koretsky, 1989). In the majority of normative documents in the field of international protection of human rights concerning the persons which are not citizens of the country in which they are, used terms "the persons which are not citizens of the country in which they live", "the faces which are not citizens of the country in which they are", "not citizens", "foreigners", etc. The analysis of international agreements shows that the sense of all these formulations is identical, but each of them has certain nuances. As a result of the deep analysis of materials of the international practice and national legal systems of the majority of members of the UN, on 28 sessions General UN Assemblies in 1977 the conclusion was drawn that the term means "the faces which are not citizens" the legal entities who do not have nationality of the country in which they are and are foreigners according to the domestic legislation of this country (The Universal Declaration of Human Rights, 1948).

\section{Conclusion}

In Kiobel against Royal Dutch Petroleum To, 621 F.3d 111 (the 2D Cir. 2010) the court noted that "the international person is the one who possesses right subjectivity in international law, that is the one who is the subject of the international law, the having rights, duties or the powers established in international law, and, in general, ability to operate on the international level. The international person means the legal entity at whom the status of the person has the international right. The concept of the international person occurs from international law." (Kiobel vs. Royal Dutch Petroleum, 621 F.3d 111 (2d Cir. 2010)). As N.I.Matuzov fairly notes, "in a modern civilized society is not present and there cannot be the people who have not been allocated with the general right ability... Duty of each state - properly to guarantee and protect this quality"(Matuzov,1972). According to it we believe that the legal entity is the certain person, possessing the rights and the duties, the international law provided by norms and having the right for the guaranteed protection of the rights at the international level. Therefore, in our opinion, the main sign of "legal entity" is ability to operate on the international level.

\section{References}

Tugarinov VP The laws of the objective world, their knowledge and use. Leningrad, 1955, pp 12-13.

E. S. Abdrakhmanova, L.B. Nyssanbekova. Treatment of Domicile Concept in International Private Law. Middle-East Journal of Scientific Research 16 (12) : 1690-1693, 2013

Gorski, S. (2013, August 3). Individuals in International Law. Retrieved April 3, 2015, from http://opil.ouplaw.com/view/10.1093/law: epil/9780199231690/law-9780199231690-e829?rskey=fCRwM6\&result=1\&prd=EPIL

Suleymenov M.K The notion of legal subjects. Journal "Law and State » № 3, 2002 . pp. 41-47

Shershenevich G.F General theory law. V.3 . Moscow, 1912 ; Op. According to the book Khropanyuk V.N Theory of State and Law : Chrestomathy. M . , 1999.873 pp.

De La Morandiere, J., (1965). Droit civil, (4e éd. ed.). Paris: Dalloz.

Kate Parlett. The Individual in the International Legal System. Continuity and Change in International Law. Cambridge: Cambridge University Press, 2010. Pp. 462 . £ 70 . ISBN: 9780521196666.

Cheshire G.C. Private International Law. 6 -th ed. Oxford, 1961

See Suleimenov M.K The notion of legal subjects. Journal "Law and State » № 3, 2002 . pp. 41-47

A. Yakimov The legal personality ( theoretical question ) Magazine "State and Law » № 4,2003, p.21-28

Abashin E. Legal capacity/ E.Abashin.-M:Yurist, 2010.-148 p

Kechekyan S.F. Legal relationships in socialist society. M., 1958. S.84

Halfina, R.O. General doctrine of legal relations. M., 1974. S.31,114-115.

Chechot D. M. Subjective right and forms of its protection. L., 1968. S.16;

Chezare Sanfillino . Rate Roman private law : Textbook. Translation from Italian M. 2000.s.235;

Alekseev S.S. Private Law. Scientific and journalistic essay . M. , 1999. 
Bachrach D.N. Subjects of the Soviet system of administrative law / / Sov. state and right . 1986 . № 2 . pp. 41 Koretsky V.M. Selected works : in 2 books. Book. 2 . Kiev, 1989.

The Universal Declaration of Human Rights on December 10, 1948 / / International law in selected works Kiobel vs. Royal Dutch Petroleum, 621 F.3d 111 (2d Cir. 2010).

Matuzov N.I Personality. The right . Democracy / Theoretical problems of subjective rights . - Saratov , 1972 . - P.73 . 